\title{
EMF Shielding Effectiveness Depending on Location of Yarns with Metal Filaments in Fabric
}

\author{
Marianna Grecka ${ }^{1}$, Olegs Artamonovs ${ }^{2}$, Juris Blums ${ }^{3}$, Andrea Ehrmann ${ }^{4}$, Ausma Vilumsone ${ }^{5}$ \\ 1,5 Institute of Design Technologies, Faculty of Materials Science and Applied Chemistry, Riga Technical University, \\ ${ }^{2}$ Institute of Radio Electronics, Faculty of Electronics and Telecommunications, Riga Technical University, \\ ${ }^{3}$ Institute of Technical Physics, Faculty of Materials Science and Applied Chemistry, Riga Technical University, \\ ${ }^{4}$ Faculty of Textile and Clothing Technology, Niederrhein University of Applied Sciences
}

\begin{abstract}
Using three types of yarns with metal filaments, textile samples with various arrangements of yarns and mutual combinations were made with an industrial loom. Textile shielding effectiveness (SE) characteristics were measured using a waveguide method and network analyzer with radiated frequency $1.161 \mathrm{GHz}$ to identify metal filament fabrics with the highest SE.
\end{abstract}

Keywords - Shielding effectiveness, textiles, metallized threads, waveguide.

\section{INTRODUCTION}

The electromagnetic (EM) spectrum includes all types of EM radiation: non-ionizing radiation - radio waves, microwaves, infrared light, visible light and ionizing radiation - ultraviolet light, X-rays, gamma rays (1). With fast development and continuous use of communication technologies the environment gets more polluted with electromagnetic fields (non-ionizing radiation) that can cause negative effects on vital functions of living creatures (2), (3).

EM shielding protects devices/people from electromagnetic waves, which have negative influence, using special shields, screens and electronic equipment (1). Numerically the shielding effectiveness (SE) can be defined as the relative amount of reflected and absorbed radiation at a particular wavelength. SE is measured in $\mathrm{dB}$ which refers to a logarithmic scale. SE can range from $0 \mathrm{~dB}(\mathrm{SE}=0 \%)$ to $-60 \mathrm{~dB}(\mathrm{SE}=99.99 \%)$. Screens and shields can also be made from textile materials (woven and knitted fabrics, non-woven materials) with various structures of conductive yarns/threads - synthetic and natural fibres as well as metals and even carbon (4)-(8). For example, woven fabrics (plain weave) from flax incorporating coated yarns with different content and distribution of silver have been developed and researched. The samples consisted of metallized yarns incorporated only in weft direction, only in warp direction and in both weaving systems make a grid of conductive yarns. Distances between the conductive yarns were $10 \mathrm{~mm}$ and $20 \mathrm{~mm}$. Samples were exposed to $0.02-0.05 \mathrm{MHz}$ and $2.4 \mathrm{GHz}$ frequency radiation. The results showed that the more metallized yarns fabric had, the better SE was observed (9).

Another research concerning SE was carried out on fabrics made from blended stainless steel and polyester yarns in combination with cotton yarns. Several groups of samples were made: fabric with different weft density of conductive yarns, fabric with varying distance of conductive yarns in weft, fabric with varying stainless steel content, fabric with varying grid size openings. Samples were irradiated with electromagnetic waves that had frequency from $300 \mathrm{kHz}$ to $1.5 \mathrm{GHz}$. High SE was observed in frequency $0.68 \mathrm{GHz}$ for samples with increased weft density, with increased proportion of conductive yarn in weft, with conductive yarns in both directions. The highest shielding value of $53.04 \mathrm{~dB}$ was obtained for the fabric with maximum stainless content in the same frequency (10).

In the study of Zhe Liu SE was measured depending on structures of fabric weave (plain, twill and satin) and density of warps and wefts. Samples consisted of stainless steel, polyester and cotton fibre blended yarn and were irradiated by EM radiation with frequency $2.2-2.65 \mathrm{GHz}$. As the density of fabric increased, SE also increased. The SE of plain weave was the highest, followed by that of twill weave; satin weave had the lowest SE (11).

To measure SE equipment/methods as an anechoic chamber (12), waveguide and network analyzer (13) are used or SE is measured by completely shielding textile bags in which the radiating device is deposited and after wards the difference is measured (14).

In most studies fabrics with metallized/carbon yarns are used in both weaving systems (warps and wefts). In this study we present fabrics that were partly of metal yarns and metal yarns were used only in weft direction. Such choice was grounded on, firstly, less consumption of metal yarns, which may lead to smaller expenses of production, and, secondly, to clarify the SE of such fabrics.

The aim of the study was to determine the EMF (electromagnetic field) shielding effectiveness of textiles with different content of metal yarns, also depending on their proportional arrangement in fabric and orientation of samples relative to the radiation source, frequency $1.161 \mathrm{GHz}$ (GPS, mobile phones, telecommunication).

\section{EXPERIMENTAL}

\section{A. Materials}

Carrying out the selection of metallized yarns, several factors were taken into account: the conformity to textile yarns, the structure and chemical consistency of the yarn, the resistivity of metal filaments, harmlessness to human health and the possibility to use the yarns in a weaving loom. For developing the samples three types of partly metal yarns were used (see Fig. 1). 


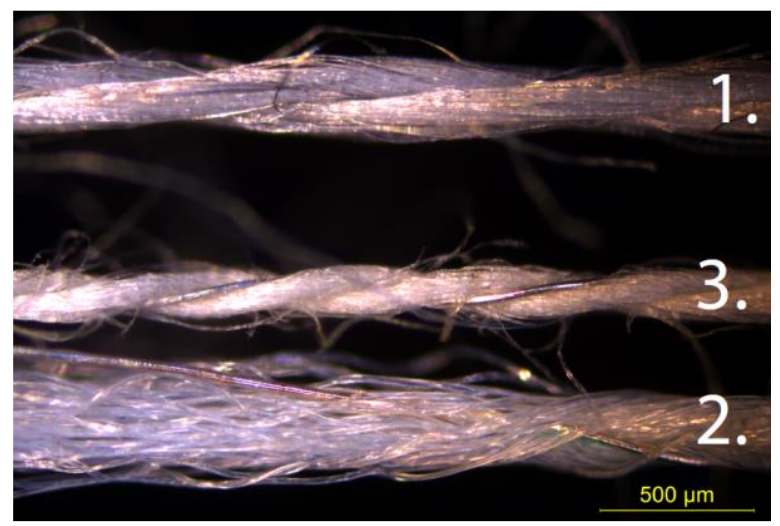

Fig.1. Micrograph of yarns: No. 1 - two-plied twisted polyester staple yarn with steel filaments (PES yarn, fine steel filaments $F G$ 5005), diameter of metal filament is $0.01 \mathrm{~mm}$, No. 2 - low twisted textured polyester multifilament yarn with steel filament (Trevira Neckelman, Nr. S06316 Jet Lavtex conductive, dtex 360 F65 x 1), $d=0.03 \mathrm{~mm}$; No. 3 - two-ply twisted cotton yarn with $\mathrm{Cu}$ filament coated with $\mathrm{Ag}$ (Cotton Acier, A067 nm), d = $0.03 \mathrm{~mm}$.

Fabric samples of canvas weave were made with industrial pneumatic loom Omni-4-R (type 2662, producer: Picanol) using partly metal yarns and polyester multifilament yarn in weft direction and polyester multifilament yarn in warp direction. The weft density is 140 yarns per $10 \mathrm{~cm}$ (14 yarns per $1 \mathrm{~cm}$ ), warp density is 400 yarns per $10 \mathrm{~cm}$. Border of variations of weft yarns were defined on the basis of the length of EM waves which irradiated the samples. If the metal yarns would be used in both weaving systems, then the dimensions of the square cell (formed by weft and warp metal yarns) should be less than $1 / 20$ of the wavelength. The EM wave could not pass through a cell of these dimensions. It was calculated that a cell of $1 \mathrm{~cm} \times 1 \mathrm{~cm}$ size could reflect the wave with frequency $1.161 \mathrm{GHz}$. Thus, in this study the weft metal yarns were used in different combinations within the width of $1 \mathrm{~cm}$. The combinations of partly metal and polyester yarns are shown in Table I. The samples of the first group have proportionally increasing number of metallized and polyester yarns per pattern repeat, while in the second group the overall number of metallized and polyester threads is kept constant. For example, Fig. 2 shows the fabric sample with code 3_2-2, where yarn No. 3 is used in combination with polyester yarn. The first number of the code identifies the metal yarn number which is used in fabric sample (e.g., yarn No. 3). The second number identifies the amount this metal yarn ( 2 yarns), and the third number - the amount of polyester yarns ( 2 yarns). The rest fabric samples are coded analogous to this example.

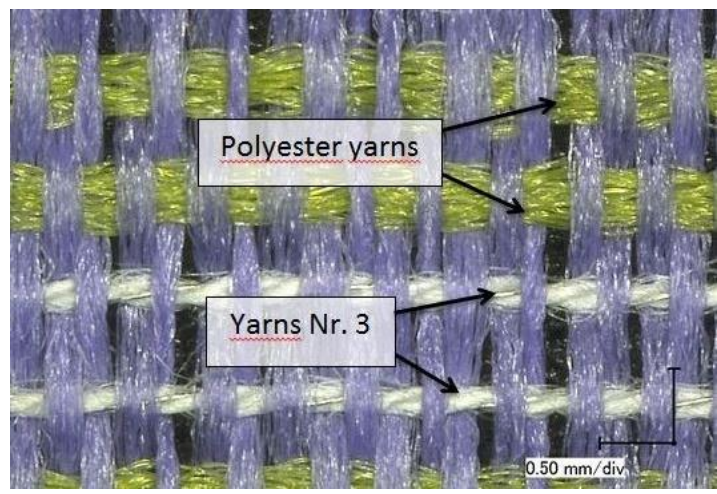

Fig.2. Fabric sample of two polyester yarns and yarns No. 3 (3_2-2).

\section{B. Measurement Method}

A test set of two similar waveguides and vector network analyzer (VNA) was used to measure the shielding effectiveness. The waveguides are cylindrical, diameter $190 \mathrm{~mm}$ and length $400 \mathrm{~mm}$. The cut-off frequency of the waveguide is approximately $1 \mathrm{GHz}$, which means that it cannot be used for lower frequencies. The linearly polarized wave inside the waveguide was generated with a quarter wave monopole. The monopole is soldered to the central wire of $\mathrm{N}$ type connector (a radio frequency coaxial connector) and placed $70 \mathrm{~mm}$ from a wall. Waveguide ports are connected with coaxial cables to the VNA ports. The test set scheme is shown in Fig. 3 a.

TABLE I

THE PATTERN REPEAT AND NUMBER OF THE WEFT YARNS

\begin{tabular}{|c|c|l|l|l|l|l|l|l|l|l|l|l|l|}
\hline Yarn No. & \multicolumn{9}{|c|}{$1^{\text {st }}$ group } & \multicolumn{4}{c|}{$2^{\text {nd }}$ group } \\
\hline No. 1 & $1 \_1-0$ & $1 \_1-1$ & $1 \_2-2$ & $1 \_4-4$ & $1 \_8-8$ & $1 \_16-16$ & $1 \_1-14$ & $1 \_3-12$ & $1 \_5-10$ & $1 \_7-8$ & $1 \_9-6$ & $1 \_11-4$ & $1 \_13-2$ \\
\hline Sample density $\left(\mathrm{g} / \mathrm{m}^{2}\right)$ & 101.6 & 85.6 & 86.2 & 85.8 & 85.2 & 85.6 & 71.3 & 76.1 & 70.1 & 83.6 & 88.5 & 91.8 & 98.1 \\
\hline No. 2 & $2 \_1-0$ & $2 \_1-1$ & $2 \_2-2$ & $2 \_4-4$ & $2 \_8-8$ & $2 \_16-16$ & $2 \_1-14$ & $2 \_3-12$ & $2 \_5-10$ & $2 \_7-8$ & $2 \_9-6$ & $2 \_11-4$ & $2 \_13-2$ \\
\hline Sample density $\left(\mathrm{g} / \mathrm{m}^{2}\right)$ & 93.6 & 82.4 & 81.4 & 81.2 & 81.2 & 82.5 & 70.9 & 74.6 & 76.7 & 80.8 & 83.5 & 86.6 & 89.9 \\
\hline No.3 & $3 \_1-0$ & $3 \_1-1$ & $3 \_2-2$ & $3 \_4-4$ & $3 \_8-8$ & $3 \_16-16$ & $3 \_1-14$ & $3 \_3-12$ & $3 \_5-10$ & $3 \_7-8$ & $3 \_9-6$ & $3 \_11-4$ & 3_13-2 \\
\hline Sample density $\left(\mathrm{g} / \mathrm{m}^{2}\right)$ & 68.7 & 69.3 & 68.7 & 69.1 & 69.2 & 68 & 69.6 & 69.5 & 69.3 & 68.4 & 68.4 & 68.5 & 67.9 \\
\hline
\end{tabular}




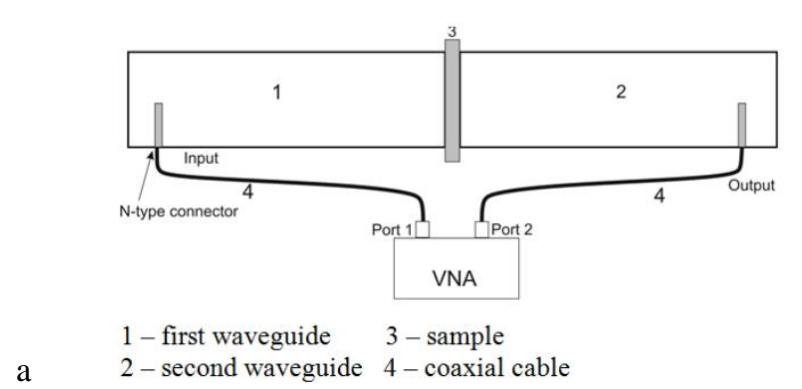

b

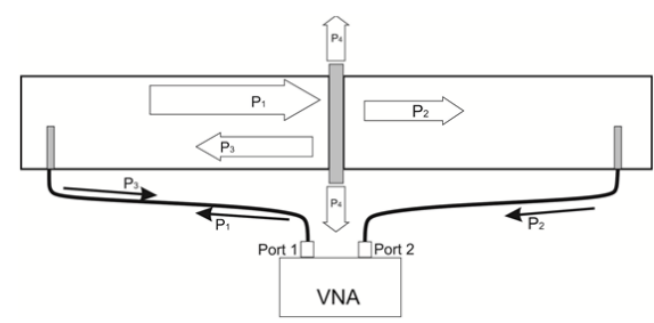

Fig.3. Scheme of waveguide and network analyzer (a), distribution of waves (b).

Waveguide characteristics were tested without a sample before SE measurements. Frequency was swept in the 0.5$1.5 \mathrm{GHz}$ range. Fig. 4 a shows the input and transition characteristics; the transition attenuation is about $1 \mathrm{~dB}$. This means that most of the input power reaches the output. The best impedance matches between VNA and waveguide ports is on frequency $1.16 \mathrm{GHz}$. Thus, this frequency was used for SE measurements. The measurement set was calibrated and normalized using VNA calibration regime. The diagram of reflected and transmitted power is illustrated in Fig. 4 b. The level of the reflected power is very low at $-71 \mathrm{~dB}\left(7.9 \cdot 10^{-8}\right.$ times less in comparison to the input power), but the level of the transmitted power is almost the same as the input power.

a

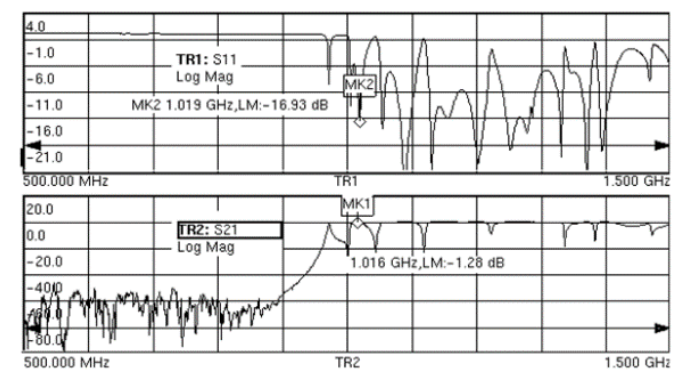

b

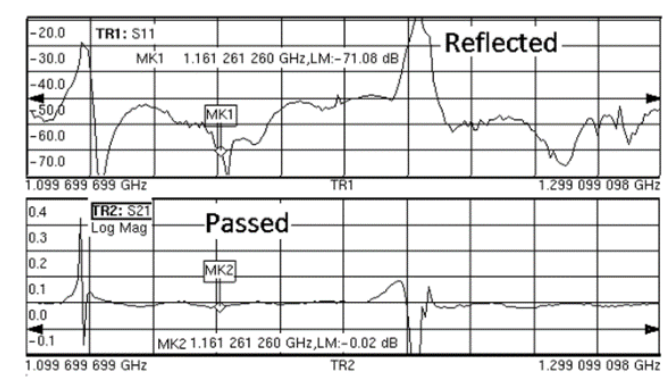

Fig. 4. Waveguide test: input reflection and transition (a), input and transient characteristics of waveguide after normalization (b).
An object placed between the waveguides will disturb the distribution of electromagnetic waves; it is shown in Fig. 3 b, where $\mathrm{P}_{1}$ is forward power, $\mathrm{P}_{2}$ is transmitted power, $\mathrm{P}_{3}$ is reflected power and $\mathrm{P}_{4}$ is absorbed power. Sum of $\mathrm{P}_{2}, \mathrm{P}_{3}$ and $\mathrm{P}_{4}$ equals $\mathrm{P}_{1}$.

Physically the forward RF (radio frequency) power is approximately $1 \mathrm{~mW}$. In this test relative powers were used. $\mathrm{P}_{1}$ was defined as $1.0(100 \%)$. VNA detects S-parameters and depicts them in a logarithmic scale. $S_{12}$ is the transition coefficient (Eq. 1), $S_{11}$ is the reflection coefficient (Eq. 2). From $S_{11}$ and $S_{12}$, reflected and transmitted relative powers can be extracted.

$$
\begin{aligned}
& \mathrm{S}_{12}=10 \log \left(\mathrm{P}_{2} / \mathrm{P}_{1}\right)=10 \log \left(\mathrm{P}_{2}\right) \\
& \mathrm{S}_{11}=10 \log \left(\mathrm{P}_{3} / \mathrm{P}_{1}\right)=10 \log \left(\mathrm{P}_{3}\right)
\end{aligned}
$$

\section{RESULTS AND DISCUSSION}

Samples under examination were oriented in such way that conductive yarns were parallel (vertically oriented sample) and perpendicular (horizontally oriented sample) to the polarization plane of the electromagnetic wave.

Horizontally oriented samples showed less shielding effectiveness than vertically oriented ones. Samples with yarn No. 1 in the $1^{\text {st }}$ group (Fig. 5 a) transmitted $\sim 60 \%$ of the radiated power, while in the $2^{\text {nd }}$ group (Fig. 5 b) there was a tendency that increasing the amount of metallized yarns also increased the shielding effectiveness. Sample with all metal weft yarns showed negative absorption; this needs more detailed investigation. The same results were observed for the majority of samples of yarn No. 2 and yarn No. 3; more particular research is needed.
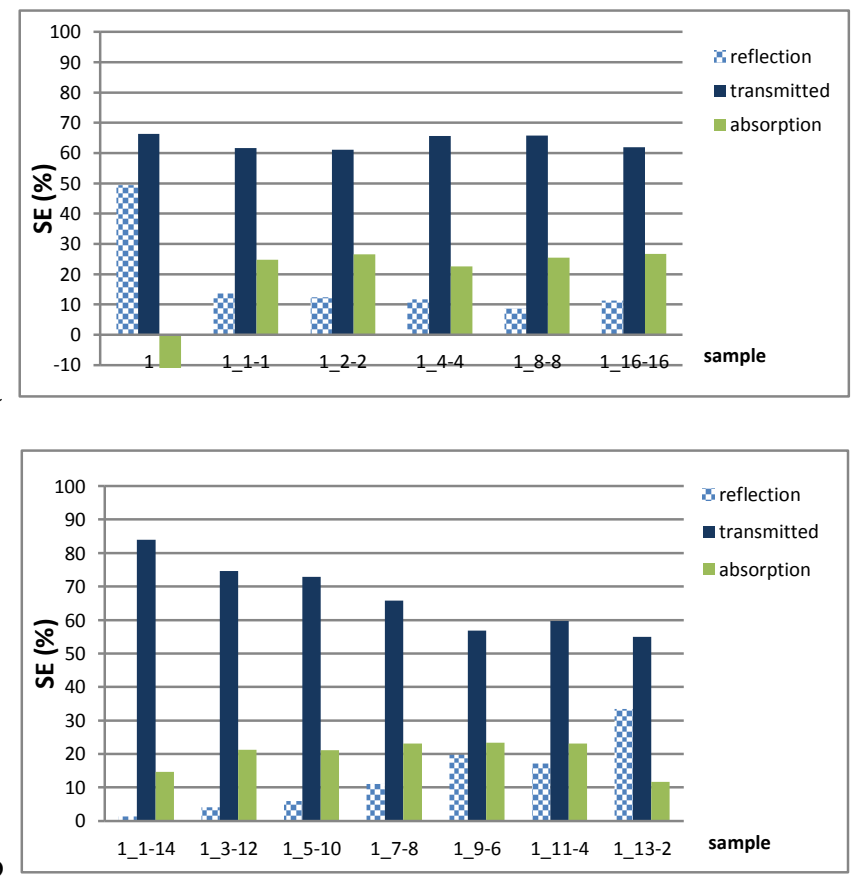

Fig. 5. Shielding effectiveness of fabrics oriented horizontally with yarn No. 1, $1^{\text {st }}$ group (a) and $2^{\text {nd }}$ group (b). 
Samples oriented vertically (Fig. 6 and Fig. 7) to the radiation source had very high SE (almost all above $70 \%$ and higher). In the $1^{\text {st }}$ group fabric samples with yarn No. 1 had slightly higher power absorption and less SE compared to other fabrics with partly metal yarns. This finding can be explained by higher electric resistivity of yarn No. 1, because it consisted of steel staple fibres, while yarn No. 2 and yarn No. 3 contained metal filaments with larger diameter, and, thus, had lower resistivity.
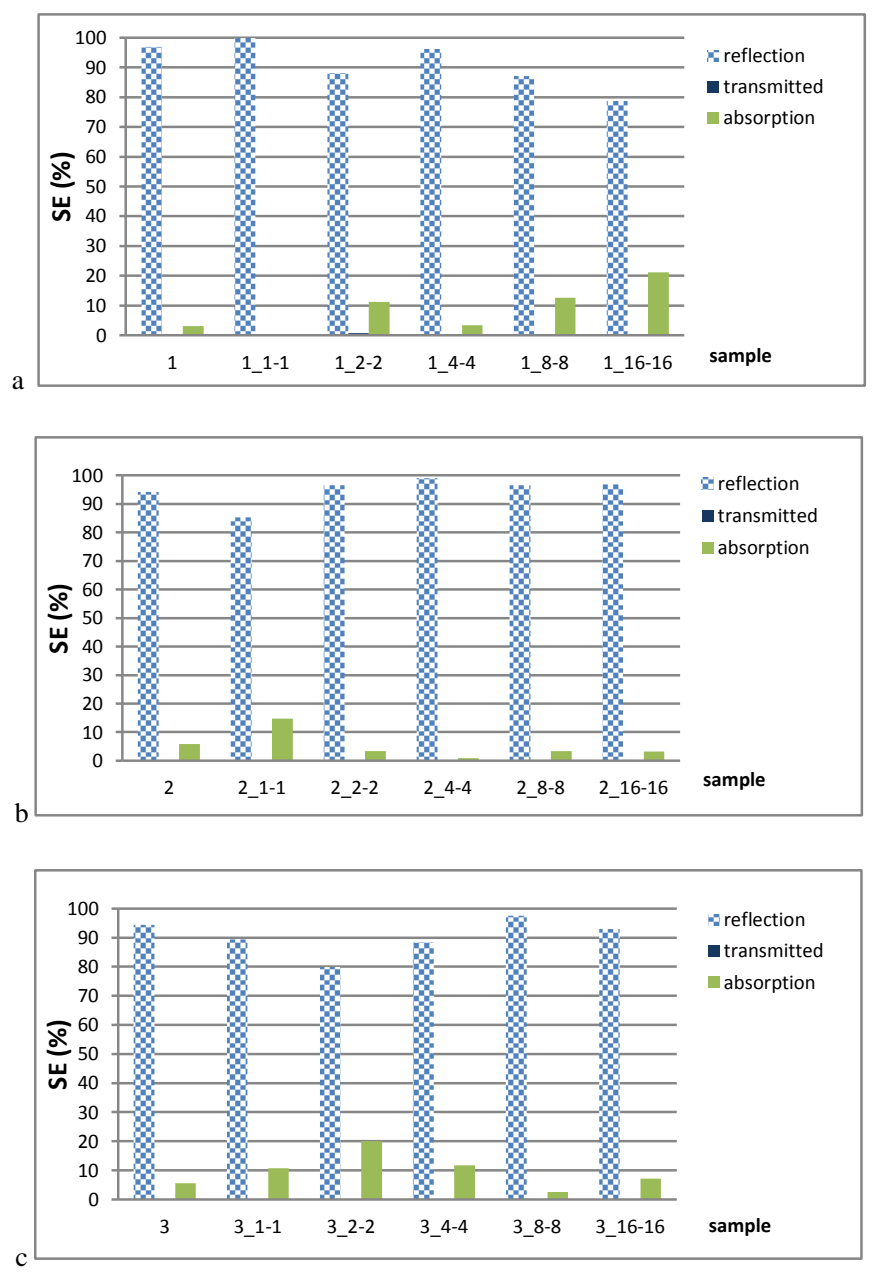

Fig. 6. Shielding effectiveness of fabrics of the $1^{\text {st }}$ group oriented vertically with yarn No. 1 - (a), yarn No. 2 - (b) and yarn No. 3 - (c).

In the $2^{\text {nd }}$ group (Fig. 7) it was observed that samples with yarn combination 1-14 had the lowest SE, as it was expected due to lower amount of conductive material included. The second lowest SE ( 70 \%) was shown by samples of yarn No. 2 with weft combinations of 9-6 and 13-2 (Fig. 7 b). Higher SE (above $90 \%$ ) and less absorption were mainly typical of samples with yarn pattern 3-12, 5-10 and 7-8.
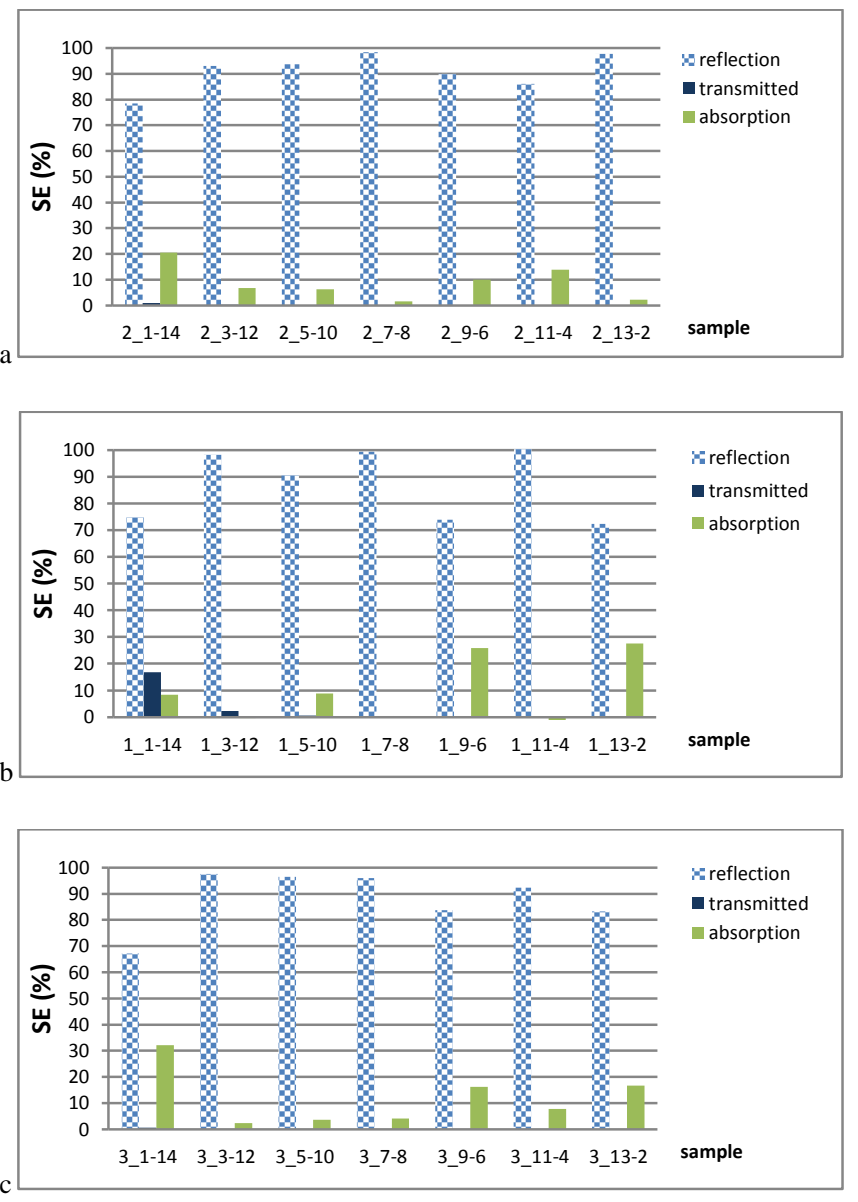

Fig. 7. Shielding effectiveness of fabrics of the $2^{\text {nd }}$ group oriented vertically with yarn No. 1 - (a), yarn No. 2 - (b), and yarn No. 3 - (c).

\section{CONCLUSION}

Samples with weft yarns oriented parallel to the polarization plane of incident electromagnetic waves showed much higher SE compared to perpendicularly oriented samples; this was caused by wave polarization. The largest EMF shielding effectiveness was observed for the $1^{\text {st }}$ group of samples with yarns containing steel filament (accordingly yarn No. 2). The SE can be influenced by such factors as: combinations of partly metal yarns, metal types in the yarn, orientation to the radiation source and the structure of the metal filament.

\section{REFERENCES}

1. Latvijas brīvo arodbiedrību asociācija. Darba higiēna. Rīga: Latvijas labklājības ministrija, 2010.

2. Genuis, Stephen J., Fielding a current idea: exploring the public health impact of electromagnetic radiation. Public Health, vol. 122, 2008, pp. 113-124. http://dx.doi.org/10.1016/j.puhe.2007.04.008

3. Roosli, M. et al., Symptoms of ill health ascribed to electromagnetic field exposure - a questionnaire survey. International Journal of Hygiene and Environmental Health, vol. 207. 2004. http://dx.doi.org/10.1078/14384639-00269

4. 3M Electronics. [online]. [viewed 6 March 2013]. Available from: http://solutions.3m.com/wps/portal/3M/en_US/Electronics_NA/Electron ics/Products/Product_Catalog

5. Less EMF. [online]. [viewed 20 March 2013]. Available from: http://www.lessemf.com/fabric.html\#1232 
6. Lorix Ltd. [online] [viewed 6 May 2013]. Available from: http://lorixen.shp.hu/hpc/web.php?a=lorixen\&o=non_woven_metallized_textiles_r2AQ

7. Marburg Technic. [online]. [viewed 6 March 2013]. Available from: http://www.martech-systems.de/no_cache/en/products/shop/pl/singleview.html?tt_products\%5BbackPID\%5D=199\&tt_products\%5Bproduct $\% 5 \mathrm{D}=715 \& \mathrm{cHash}=\mathrm{cea} 0 \mathrm{ee} 82681 \mathrm{~d} 225 \mathrm{~b} 0 \mathrm{ae} 9 \mathrm{~d} 05 \mathrm{~b} 8 \mathrm{c} 0 \mathrm{a} 78 \mathrm{bb}$.

8. SGL Group. [online]. [viewed 15 May 2013]. Available from: https://www.sglgroup.com/cms/international/products/productgroups/cf/carbon-fibers-for-intake-fittings/index.html?_locale=en

9. Baltušnikaite, J. et al., Influence of Silver Coated Yarn Distribution on Electrical and Shielding Properties of Flax Woven Fabrics, Fibres \& Textiles in Eastern Europe, 2014, vol. 22, no. 2(104), pp. 84-90.

10. Electromagnetic Interference Shielding Effectiveness of SS/PET Hybrid Yarn Incorporated Woven Fabrics, Das, A., etc., Fibers and Polymers 2014, Vol.15, No.1, 169-174, http://dx.doi.org/10.1007/s12221-0140169-0

11. Liu, Zh., et al., Influence of Metal Fiber Content nad Arrangement on Shielding Effectiveness for Blended Electromagnetic Shielding fabric, Materials science (Medziagotyra), ISSN 1392-1320, vol. 21, no. 2. 2015. http://dx.doi.org/10.5755/j01.ms.21.2.6529

12. Kowal, M., Kubal, S., Zielinski, R. J., Measuring the shielding effectiveness of large textile materials in an anechoic chamber, 8/12, IEEE, 2012. http://dx.doi.org/10.1109/EMCEurope.2012.6396852

13. Mistik, S. I., Sancak, E., et al., Investigation of electromagnetic shielding properties of boron and carbon fiber woven fabrics and their polymer composites, Proceedings, RMUTP International Conference: Textiles \& Fashion, July 3-4, 2012, Bangkok, Thailand.

14. Vojtech, L., Neruda, M., Application of shielding textiles for increasing safety airborne systems, 978-0-7695-3979-9/10, IEEE, 2010. http://dx.doi.org/10.1109/ICN.2010.35

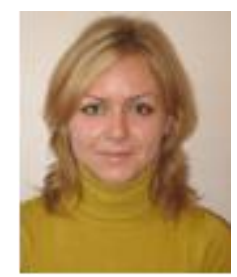

Marianna Grecka, Mg. sc. ing., is a Doctoral student in the Institute of Design Technologies, Riga Technical University. She received a Professional Bachelor's Degree in Material Technology and Design in 2010 and a Professional Master's Degree in Clothing and Textile Technology in 2012. The title of her Doctoral thesis is Projection of Functional Clothing.

She was a researcher (2011-2012) in the Institute of Technology and Design of Textile Materials, Riga Technical University. Now she is Project\&Textile materials manager, Develop Baltic, Ltd.

Her scientific interests are: smart textiles, integration of electronics in clothing.

Address: Institute of Design Technologies, Riga Technical University, Kipsalas Str. 6, Riga, LV-1048, Latvia.

E-mail: marianna.grecka@rtu.lv

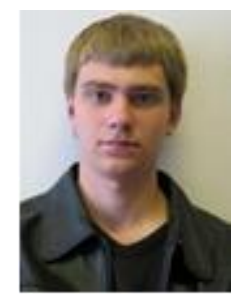

Olegs Artamonovs Mg. sc. ing., is a Doctoral student in the Institute of Electronics, Riga Technical University. He received Bachelor's degree in Electrical Engineering in 2010 and Master's degree in Electronics in 2012 from Riga Technical University. The title of his Doctoral thesis is Wearable Antenna.

His scientific interests are: micro strip patch antennas, electromagnetics.

Address: Institute of Radio Electronics, Riga Technical University, Azenes str. 16, Riga, LV-1048, Latvia.

E-mail: olegs.artamonovs@rtu.lv

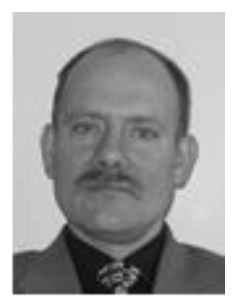

Juris Blums, Dr. phys. (University of Latvia, 1997), Associate Professor (Riga Technical University, since 2003).

J. Blums was a visiting researcher in Experimental Physics in Tallinn Technical University (Estonia, 2000), University of Essen (Germany, 2001-2003). His scientific interests are: semiconductor physics, laser-matter interaction, solar batteries.

Address: Institute of Technical Physics, Riga Technical University, Paula Valdena str. 3, Riga, LV-1048, Latvia.

E-mail: blum@latnet.lv

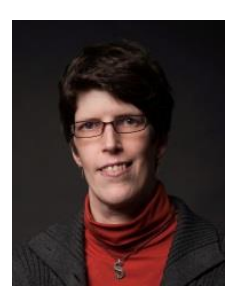

Andrea Ehrmann, Dr. rer. nat., Dr. n. techn., Degree. Since 2005 she has been with the Faculty of Textile and Clothing Technology, Moenchengladbach, the Niederrhein University of Applied Sciences. She graduated from RWTH Aachen University (Germany) in 2001 as Dipl.-Phys and received the Doctoral degree in 2005 from the RWTH Aachen University (magneto-optics) and the Doctoral degree in 2014 from the Silesian University of Technology, Gliwice, Poland (examination and simulation of magnetic nano-structures).

Her research interests include smart textiles, knitting, microscopy, simulation and experimental investigation of physical properties of advanced materials.

Address: Faculty of Textile and Clothing Technology, Niederrhein University of Applied Sciences, Webschulstr. 20, D-41065, Moenchengladbach, Germany

E-mail: andrea.ehrmann@hs-niederrhein.de

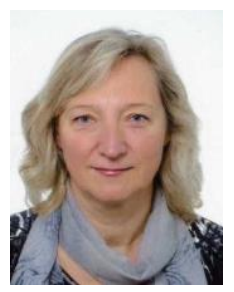

AusmaVilumsone, Dr. sc. ing., Professor, with Institute of Design Technologies, Riga Technical University. She is Head of the Department of Clothing and Textile Technologies. Her scientific interests are: development and optimization of garment design technological process, CAD/CAM systems in product design, innovative materials and technologies.

Address: Institute of Design Technologies, Riga Technical University, Kipsalas str. 6, Riga, LV-1048, Latvia.

E-mail: ausma.vilumsone@rtu.lv

Marianna Grecka, Oḷegs Artamonovs, Juris Blūms, Andrea Ehrmann, Ausma Viḷumsone. Elektromagnētiskā lauka ekranēšanas efektivitāte atkarībā no metalizēto pavedienu izvietojuma audumā

Strauji attīstoties komunikācijas tehnologiju sistēmām, ir krasi palielinājusies apkārtējās vides piesārnojuma ar elektromagnētisko starojumu bīstamība. Elektromagnētisko viļ̣u ekranēšana ir nepieciešama ne tikai elektroniskām ierīcēm, bet arī cilvēkiem. Ekranējošo tekstiliju izmantošana apgèērbā ir viens no veidiem kā pasargāt cilvēku no EM viḷniem. Šādas var būt austās, neaustās, pārklātās un adītās tekstilijas. Ekranēšanas efektivitātes mērīšanai izmanto vairākas metodes, kuru iekārtu atšşirīibas galvenokārt nosaka viḷnu garumi, ar kuriem apstaro paraugus. Darba mērḳis ir izveidot auduma paraugus ar elektromagnētiska lauku ekranējošām īpašīīām, izmantojot trīs dažādus metalizētus pavedienus: 1. pavediens - poliestera un tērauda štāpel̦šş̧iedras pavediens, 2. - multifilamentārais PES pavediens ar tērauda filamentu, 3. kokvilnas šķiedru un vara filaments, kas pārklāts ar sudrabu. 
Paraugi austi uz vienšķīiienu pneimatiskām stellēm Omni-4-R audekla pinumā, kombinējot audu metalizētus un poliestera pavedienus. Kopumā izveidoti 36 paraugi. Paraugu ekranēšanas efektivitāte mērīta, izmantojot divus viļ̣nvadus, starp kuriem novietots paraugs un ar ķēžu analizatoru (raidītā viḷna frekvence $1,16 \mathrm{GHz}$ ).

Vislabākās ekranēšanas īpašības piemīt paraugiem, kuru metalizētie pavedieni ir novietoti vertikāli, jo viḷna elektriskā lauka polarizācija sakrīt ar ieaustā vadītāja (metalizētā pavediena) orientāciju. Kopumā salīdzinot auduma paraugus, vidējs atstarošanas rādītājs ir virs 70 \% no raidītā vilna.

Visaugstākā ekranēšanas efektivitāte ir paraugiem ar pavedieniem ar tērauda filamentu (attiecīgi pavedieni Nr. 2). Ekranēšanas efektivitāti ietekmē šādi faktori: metalizētu un poliestera pavedienu kombinācija, metāla veids pavedienā, metalizēta pavediena struktūra un parauga novietojums attiecībā pret starojuma avotu.

Марианна Грецка, Олег Артамонов, Юрис Блум, Андреа Эрман, Аусма Вилюмсоне. Эффективность экранирования электромагнитного поля в зависимости от расположения металлизированных нитей в ткани

В связи с быстрым развитием систем коммуникационных технологий, резко возросла опасность загрязнения окружающей среды электромагнитным излучением. Экранирование электромагнитных волн необходимо не только для электронных устройств, но и для людей. Одним из способов защиты людей от ЭМ волн является использование экранирующих текстильных изделий. Текстильный материал может быть тканым, нетканым, вязаным и с покрытием.

Для измерения эффективности экранирования используются разные методики, различающиеся в основном по длине волн, облучающих образцы. Цель работы - создать тканые образцы, экранирующие электромагнитное поле, используя три разных металлизированных нити. Первая нить - из полиэстера и стального штапельного волокна, вторая нить - из мультифиламентарного полиэстера со стальным филаментом, третья нить - из хлопкового волокна и медного филамента, покрытого серебром.

Образцы сотканы на пневматическом станке "Омни-4-R" полотняного переплетения, металлизированные и полиэфирные нити были скомбинированы. Создано 36 образцов из металлизированных и полиэфирных нитей. Эффективность экранирования образцов измерена с использованием двух волноводов, между которыми расположен образец, и анализатора (частота волны 1.16 ГГц).

Наилучшая эффективность экранирования характерна для вертикально расположенных образцов, потому что поляризация электрического поля волны совпадает с ориентацией проводника (металлизированной нити). Средний показатель эффективности экранирования составляет свыше $70 \%$. Наибольшая эффективность экранирования наблюдается у образцов со стальным филаментом (т. е. нитями № 2).

Эффективность экранирования зависит от таких факторов, как комбинация металлизированных и полиэфирная нитей, тип металла, структура металлизированных нитей и позиции образца относительно источника излучения. 